\title{
Corrected Heat of Combustion and Formation Values for a Number of Organic Sulphur Compounds
}

\author{
S. S U N N ER \\ Thermochemistry Laboratory*, University of Lund, Sweden
}

\begin{abstract}
Heat of combustion measurements for sulphur compounds performed at the Thermochemistry Laboratory during the early stages of development of rotating-bomb calorimetry have been recalculated to yield data concordant with present day knowledge. Heat of combustion and heat of formation data are thus given for 17 organic sulphur compounds at $25^{\circ} \mathrm{C}$.
\end{abstract}

$\mathbf{I}_{\mathrm{n}}^{\mathrm{n}}$ 1949 when the first full account was published on rotating-bomb calorimetry applied to organic sulphur compounds, the method suffered from several weaknesses. These were overcome during the following years by developmental work carried out primarily at the Thermodynamics Laboratory, Petroleum Research Centre, US Bureau of Mines, Bartlesville, and in our laboratory $* *$. Of great concern was the significant difference between the heat of combustion values for elemental sulphur obtained in Bartlesville and in Lund ${ }^{1}$. Fortunately, this very disturbing discrepancy has recently been removed and to-day the method can be said to be highly reliable.

A revaluation of all data obtained during the years 1949-1955 has therefore been undertaken, as all the necessary auxiliary data is available in the publications $* * *$. The recalculations involve the following changes:

1. Conversion to the standard reference temperature, $25^{\circ} \mathrm{C}$.

2. Corrections to standard states according to the procedure given in Ref.1, Chapter 5 .

* Sponsored by the Swedish Natural Science Research Council and by the Swedish Technical Research Council.

** For a review see Ref. ${ }^{1}$.

*** Prior to 1949 a number of sulphur compounds were burned which have not been included in the recalculations as at that time the technique was not very well developed, the uncertainty was unsatisfactory and, further, important auxiliary data were not recorded. 
Table 1. Corrected heat of combustion and formation values at $25^{\circ} \mathrm{C}$. Where not otherwise stated the substances are liquids. Uncertainties are expressed as twice the over-all standard deviation of the mean.

\begin{tabular}{|c|c|c|c|}
\hline Substance & Ref. & $\begin{array}{c}\Delta H_{\mathrm{c}}^{\circ} \\
\text { kca.mole }\end{array}$ & $\begin{array}{c}\Delta H_{\mathrm{f}}^{\circ} \\
\text { kcal.mole }\end{array}$ \\
\hline Thiacyclopropane & $\mathbf{5}$ & -481.02 & $+12.38 \pm 0.3$ \\
\hline Thiacyclobutane & 5 & -636.78 & $+5.77 \pm 0.4$ \\
\hline 2-Methylthioacyclopropane & 5 & -633.75 & $+2.74 H 0.3$ \\
\hline Thiacyclopentane & 5,6 & - & $-17.39 \pm 0.28 *$ \\
\hline 2,2-Dimethylthiacyclopropane & 5 & -787.56 & $-5.82 \pm 0.3$ \\
\hline Cis-2,3-dimethylthiacyclopropane & 5 & -787.56 & $-5.82 \pm 0.3$ \\
\hline Trans-2,3-dimethylthiacyclopropane & 5 & -786.32 & $-7.06 \pm 0.3$ \\
\hline Thiacyclohexane & 5 & -930.34 & $-25.41 \pm 0.3$ \\
\hline Trimethylthiacyclopropane & 5 & -941.26 & $-14.49 \pm 0.3$ \\
\hline Thiacycloheptane & $\mathbf{5}$ & -1091.12 & $-27.00 \pm 0.4$ \\
\hline Tetramethylthiacyclopropane (s) & 5 & -1098.24 & $-19.88 \pm 0.4$ \\
\hline Thianthrene (s) & 7 & -1733.29 & $+43.56 \pm 0.32$ \\
\hline 5-Thianonane & 8 & -1458.42 & $-52.76 \pm 0.45$ \\
\hline Methyl-isothiocyanate (s) & 8 & -453.50 & $+19.02 \pm 0.30$ \\
\hline 1-Pentanethiol & 8 & -988.01 & $-36.06 \pm 0.20$ \\
\hline Thiophene & 9 & -676.09 & $+19.35 \pm 0.15$ \\
\hline Thiolacetic acid & 9 & -416.22 & $-52.42 \pm 0.35$ \\
\hline
\end{tabular}
cited.

* This value as given in Ref. ${ }^{5}$ has proven to be in error. A redetermination ${ }^{6}$ gave the value

3. The use of the new value for the heat of combustion of sulphur to sulphuric acid **.

4. Molecular weights based on the 1961 table of atomic weights ${ }^{4}$.

Naturally, the recalculations included all calibration series with benzoic acid and all series of measurements on the auxiliary material, paraffin oil, although these values have not been given separately.

The corrected values are presented in Table 1 . The $\Delta H_{\mathrm{c}}^{\circ}$-values refer to the isothermal combustion reaction taking place at $25^{\circ} \mathrm{C}$ :

$\mathrm{C}_{\mathrm{a}} \mathrm{H}_{\mathrm{b}} \mathrm{O}_{\mathrm{c}} \mathrm{S}_{\mathrm{d}}(\mathrm{s} / \mathrm{liq})+(\mathrm{a}+\mathrm{b} / 4-\mathrm{c} / 2+3 \mathrm{~d} / 2) \mathrm{O}_{2}(\mathrm{~g})+$

$+(116 \mathrm{~d}-\mathrm{b} / 2) \mathrm{H}_{2} \mathrm{O}(\mathrm{liq})=\mathrm{a} \mathrm{CO}_{2}(\mathrm{~g})+\mathrm{dH}_{2} \mathrm{SO}_{4}, 115 \mathrm{H}_{2} \mathrm{O}(\mathrm{liq})$

The $\Delta H \mathrm{f}^{\circ}$-values refer to the standard process at $25^{\circ} \mathrm{C}$

a $\mathrm{C}$ (graphite) $+\mathrm{b} / 2 \mathrm{H}_{2}(\mathrm{~g})+\mathrm{c} / 2 \mathrm{O}_{2}(\mathrm{~g})+\mathrm{dS}(\mathrm{c}$, rhombic) $\rightarrow$

$$
\rightarrow \mathrm{C}_{\mathrm{a}} \mathrm{H}_{\mathrm{b}} \mathrm{O}_{\mathrm{c}} \mathrm{S}_{\mathrm{d}}(\mathrm{s} / \mathrm{liq})
$$

The value for the heat of combustion at constant volume, $\Delta E_{\mathrm{c}}^{\circ}$, of rhombic sulphur according to the equation

$$
\begin{gathered}
\mathrm{S}\left(\mathrm{c}, \text { rhombic) }+3 / 2 \mathrm{O}_{2}(\mathrm{~g})+116 \mathrm{H}_{2} \mathrm{O}(\mathrm{liq}) \rightarrow\right. \\
\rightarrow \mathrm{H}_{2} \mathrm{SO}_{4}, 115 \mathrm{H}_{2} \mathrm{O}(\mathrm{liq})
\end{gathered}
$$

** The value, recently obtained at the Petroleum Research Centre, Bartlesville ${ }^{2}$ is $-212.17 \pm 0.06$ kcal.mole ${ }^{-1}$ at $25^{\circ} \mathrm{C}$ for the reaction

$$
\begin{aligned}
\mathrm{S}(\mathrm{c}, \text { rhombic }) & +\mathrm{H}_{2}(\mathrm{~g})+2 \mathrm{O}_{2}(\mathrm{~g})+115 \mathrm{H}_{2} \mathrm{O}(\mathrm{liq}) \rightarrow \\
\rightarrow & \mathrm{H}_{2} \mathrm{SO}_{4}, 115 \mathrm{H}_{2} \mathrm{O}(\mathrm{liq})
\end{aligned}
$$

From our laboratory the value $-212.24 \pm 0.07 \mathrm{kcal}^{2}$ mole ${ }^{-1}$ has just been published ${ }^{3}$.

Acta Chem. Scand. 17 (1963) No. 3 
Table 2. Comparison between data independently obtained at the Bartlesville and Lund laboratories.

$\begin{array}{lcc} & \Delta H_{\mathrm{f}}{ }^{\circ} \text { (Lund-USBM) } & \delta_{\mathrm{s}}{ }^{\prime}+\delta_{\mathrm{s}}{ }^{\prime \prime} \\ \text { Thiacyclobutane } & -0.24 & 0.23 \\ \text { Thiacyclopentane } & +0.10 & 0.30 \\ \text { Thiacyclohexane } & -0.05 & 0.25 \\ \text { 5-Thianonane } & -0.02 & 0.41 \\ \text { Pentanethiol } & -0.29 & 0.32 \\ \text { Thiophene } & +0.35 & 0.24 \\ \text { Thianthrene } & +0.38 & 0.35\end{array}$

has been taken as the average value between the Bartlesville and Lund results, $-142.99_{5} \pm 0.04_{5} \mathrm{kcal} . \mathrm{kole}^{-1}$. This figure corresponds to a value for the heat of formation of sulphuric acid (eqn. 1) of $-212.20_{5} \mathrm{kcal}_{\text {.mole }}{ }^{-1}$.

For seven of the compounds independent determinations have been performed at the Bartlesville laboratory ${ }^{10}$. Table 2 gives the differences between the Lund- and the Bartlesville-values together with the sum of the assigned uncertainties, expressed as the single over-all standard deviation of the mean. The agreement is very satisfactory and leads to the conclusion that systematic errors (or more precisely differences in systematic errors) are absent in the determinations carried out at our two laboratories.

Acknowledgement. The tedious recalculation work was done by Miss M. Månsson, whose help is greatly appreciated.

\section{REFERENCES}

1. Rossini, F. D. (Ed.) Experimental Thermochemistry. Interscience, New York 1956, Chapter 7.

2. Good, W. D., Lacina, J. L. and McCullough, J. P. J. Am. Chem. Soc. 82 (1960) 5589.

3. Månsson, M. and Sunner, S. Acta Chem. Scand. 17 (1963) 723.

4. Cameron, A.E. and Wichers, E. J. Am. Chem. Soc. 84 (1962) 4175.

5. Sunner, S. Studies in Combustion Calorimetry Applied to Organo-Sulphur Compounds. (Diss.) Lund University 1949.

6. Davies, J. and Sunner, S. Acta Chem. Scand. 16 (1962) 1870.

7. Sunner, S. and Lundin, B. Acta Chem. Scand. 7 (1953) 1112.

8. Sunner, S. Acta Chem. Scand. 9 (1955) 837.

9. Sunner, S. Acta Chem. Scand. 9 (1955) 847.

10. McCullough, J. P. Private Communication.

Received October 29, 1962. 